\section{The relationship between knowledge management and creativity in bachelor degree compared to master degree nursing students}

Banafsheh Tehranineshat ${ }^{1}$

Mahnaz Rakhshan ${ }^{2}$

The relationship between knowledge management and creativity in bachelor degree compared to master degree nursing students

Objective. To investigate the relationship between knowledge management and creativity in undergraduate compared with master degree nursing students. Methods. This cross-sectional study was conducted with nursing students of the faculty of nursing and midwifery in an urban area in the southeast of Iran from August 2017 to January 2018. In this study, 180 students were selected using a simple random sampling method (Bachelor degree=120 and Master degree $=60$ ). Data was collected using the Nonaka and Takeuchi's knowledge management and Randsip's Creativity questionnaires. Results. There was a direct and significant relationship between knowledge management and creativity in the students $(r=0.47$ in Bachelor degree and $r=0.36$ in Master degree). The mean scores of knowledge management dimensions

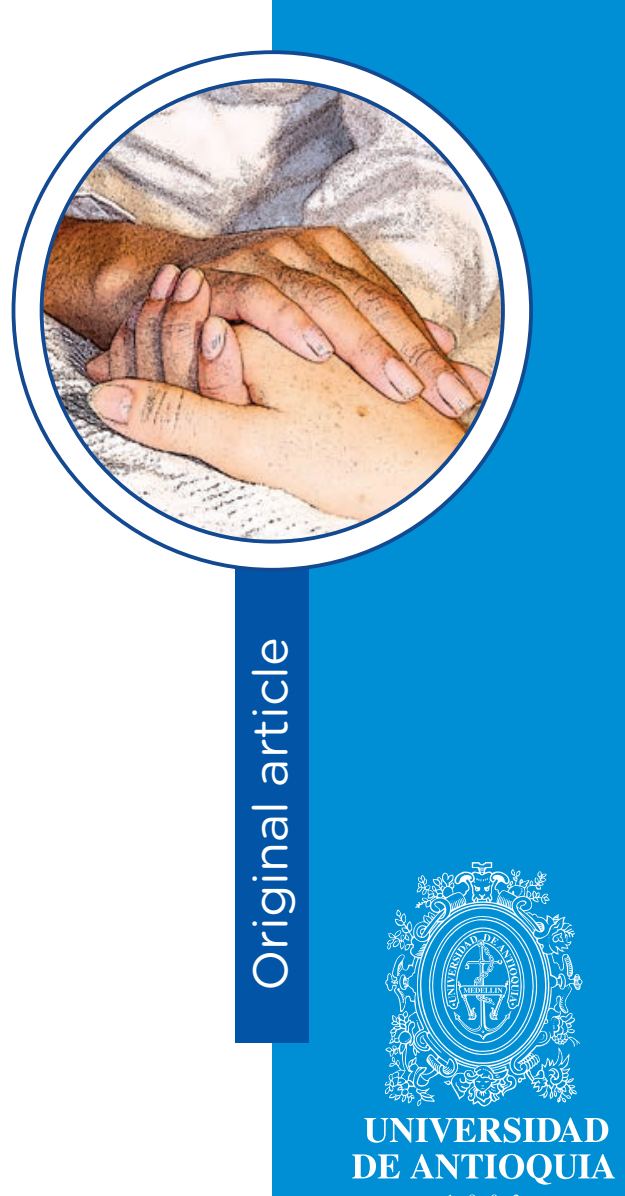

1 Nurse, Ph.D Candidate, Student Research Committee. School of Nursing and Midwifery, Shiraz University of Medical Sciences, Shiraz, Iran. email: tbanafsheh@yahoo.com

2 Nurse, Ph.D. Associate professor, School of Nursing and Midwifery, Shiraz University of Medical Sciences, Shiraz, Iran.

email: mzrakhshan@gmail.com (Corresponding Author).

Conflicts of interest: none.

Received: May 23rd, 2018.

Approved: September 19th, 2018.

How to cite this article: Tehranineshat $B$, Rakhshan $M$. The relationship between knowledge management and creativity in bachelor degree compared to master degree nursing students. Invest. Educ. Enferm. 2018; 36(3):e05.

DOI: 10.17533/udea.iee.v36n3e05 
and creativity were higher in the master degree students. Conclusion. There was a relationship between knowledge management and creativity in the bachelor and master degree students. It is necessary to corroborate the Efforts for the implementation of strategies for the knowledge management in all its dimensions. Therefore, the education environment can help with the development of students' knowledge and skills.

Descriptors: students, nursing; creativity; knowledge management; education, nursing; surveys and questionnaires.

\section{Relación de la gestión del conocimiento y la creatividad en los estudiantes de pregrado en comparación con los de la Maestría en Enfermería}

Objetivo. Investigar la relación entre la gestión del conocimiento y la creatividad en los estudiantes de pregrado en comparación con los alumnos de Maestría de Enfermería. Métodos. Este estudio de corte transversal se realizó con estudiantes de la Facultad de Enfermería y Partería en un área urbana en el sureste de Irán. Para el efecto, se seleccionaron 180 alumnos mediante un método de muestreo aleatorio simple (pregrado $=120$ y maestría $=60$ ). Los datos se recolectaron utilizando la escala de gestión del conocimiento de Nonaka y Takeuchi y el cuestionario de Creatividad de Randsip. Resultados. Hubo una relación directa y significativa entre la gestión del conocimiento y la creatividad en los dos grupos de estudiantes $(r=0.47$ en Pregrado y $r=0.36$ en Maestría). Las puntuaciones medias de los instrumentos de gestión del conocimiento y de creatividad fueron más altas en los estudiantes de Maestría. Conclusión. Hubo una relación directa entre la gestión del conocimiento y la creatividad en los estudiantes de pregrado y Maestría en Enfermería, por lo tanto, 
el entorno educativo puede ayudar con el desarrollo del conocimiento y habilidades de los estudiantes

Descriptores: estudiantes de enfermería; creatividad; gestión del conocimiento; educación en enfermería; encuestas y cuestionarios.

\section{Relação da gestão do conhecimento e a criatividade nos estudantes de graduação em comparação com os do Mestrado em Enfermagem}

Objetivo. Investigar a relação entre a gestão do conhecimento e a criatividade nos estudantes de graduação em comparação com os estudantes de Mestrado de Enfermagem. Métodos. Este estudo de corte transversal se realizou com estudantes da Faculdade de Enfermagem e Parteira em uma área urbana no sudeste de Irão. Foram selecionados 180 alunos mediante um método de amostragem aleatório simples (graduação $=120$ e mestrado $=60$ ). Os dados se coletaram utilizando a escala de gestão do conhecimento de Nonaka e Takeuchi e o questionário de Criatividade de Randsip. Resultados. Houve uma relação direta e significativa entre a gestão do conhecimento e a criatividade nos dois grupos de estudantes $(r=0.47$ em graduação e $r=0.36$ em Mestrado). As pontuações médias dos instrumentos de gestão do conhecimento e de criatividade foram mais altas nos estudantes de Mestrado. Conclusão. Houve uma relação direta entre a gestão do conhecimento e a criatividade nos estudantes de graduação e Mestrado em Enfermagem, por tanto, o entorno educativo pode ajudar com o desenvolvimento do conhecimento e habilidades dos estudantes.

Descritores: estudantes de enfermagem; criatividade; gestão do conhecimento; educação em enfermagem; inquéritos e questionários. 


\section{Introduction}

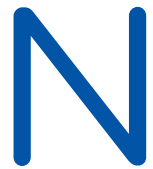

owadays, medical science universities emphasize the development of knowledge management to promote students' competencies as knowledgeable evidence-based decision-makers. knowledge is the most important asset of universities and the primary source used by nursing educators and students. University's responses to ever-increasing changes in the community are facilitated through knowledge management. In strategic planning, the mission of universities is to emphasis on the production, preservation and transfer of knowledge. ${ }^{(1)}$ The capital of educational knowledge has in the forms of explicit and tactic. ${ }^{(2)}$ Explicit knowledge is stored in official languages in databases and easily distributed among individuals. Hidden knowledge exists in the minds of individuals and is deeply embedded in the actions, experiences, values and desires of individuals. ${ }^{(3)}$ Knowledge should be managed in an appropriate manner, ${ }^{(4)}$ because it is related to the most important organizational capital as intellectual capital. ${ }^{(5)}$

The dynamic of mental and social factors is the cornerstone of the production of knowledge. The dynamism of the mind is characterized by criticism and creativity. Nursing practices are related to creative activities that lead to the production of explicit knowledge of tacit knowledge. There is a positive comorbidity between students, peers and nursing educators in building knowledge. When a student asks a question, he/she studies it with an open mind through discussions with their counterparts or educators and examines answers from different perspectives to generate new knowledge. The use of knowledge management strategies in nursing education leads to deep learning, decision-making and problem-solving by nursing students in clinical situations. The implementation of knowledge management in medical sciences universities provides an opportunity for educators, students and staff to acquire knowledge from the environment and use it in a variety of professional fields, share them and create creatively new knowledge. ${ }^{(1)}$

The importance of creativity is so high to provide innovative solutions for decision-making and problem solving when community services are provided. (6) Sometimes community health services are provided in environments where official research literature is inaccessible to guide performance. Health organizations should provide creative responses to increasingly and complex health problems, and staff creativity is changed based on the needs and aspirations of clients. ${ }^{(7)}$ In crisis and epidemics, health care providers need to reports and new Statistical information and there should be no delay in decision making. ${ }^{(8)}$ Therefore, Health sector due to association with community health need to use efficient methods for knowledge management through the use of modern information management techniques and the allocation of appropriate time. ${ }^{(9)}$ Therefore, with regard to professional challenges, it is essential for nursing students to be educated with a set of different skills and their applied 
knowledge is developed based on professional needs and problems. ${ }^{(1)}$ In other disciplines, there has been a relationship between knowledge management and creativity. Also, individuals and organizations need to use knowledge to improve their creativity, and the appropriate use of knowledge depends on creativity. ${ }^{(10)}$ In recent years, academic institutions as the center for the production and dissemination of knowledge, more than any other organization, need to consider the management of knowledge and creativity in teaching-learning for nursing students. ${ }^{(3)}$ It is believed that students should practice in all fields of healthcare and pay enough attention to the health needs of clients and family members, educate them, and provide community services within the existing knowledge framework and creativity. ${ }^{(11)}$

While in numerous studies, knowledge management and creativity have been evaluated in university instructors, school administrators, staff and librarians; so far researchers of this study have not investigated the relationship between knowledge management and the creativity among bachelor degree nursing students compared to master degree nursing students. In addition to, the results of studies showed that everyone has considered knowledge management from a particular point of view. Some have emphasized the implementation of knowledge management, and some aspects of knowledge management dimensions have been considered. In healthoriented organizations, there is a gap between knowledge management and its application, which should be bridged ${ }^{(12)}$ Considering that public health depends on the health services provided by educated healthcare staff, nursing students should be able to think critically and creatively in all areas of care in the society based on the existing knowledge framework. On the other hand, planning and providing solutions to problems are subject to comprehensive and complete information about the problem. If the skill of knowledge management and creativity in master degree students is higher than that in bachelor degree students, one can hope that the problem will be solved through increasing individuals' experiences; otherwise it can be emphasized that to increase individuals' abilities, thinking about other strategies and solutions are needed. Therefore, to investigate the relationship between knowledge management and creativity of bachelor degree nursing students compared with master degree nursing students.

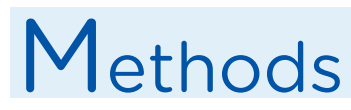

This descriptive-correlational study was carried out during August 2017 to January 2018. The population of study was undergraduate and postgraduate nursing students from a faculty of nursing and midwifery in south-eastern (Iran) ( $n=182, n=95$ respectively). The sample size was determined using the NCSS software given $\alpha=0.01, \quad \beta=0.05,95 \% \mathrm{Cl}$ and $r=0.535$. Therefore, at least 52 students for each education degree were required. Because of increasing power of study and considering that the number of undergraduate students were more than postgraduate students; therefore, 120 undergraduate students and 60 postgraduate students were recruited using a convenience sampling method.

Inclusion criteria for bachelor degree students were finishing one academic year at the time of the completion of the questionnaire. Also, for master degree students in nursing, inclusion criteria were completion of at least one academic semester at the time of the study and one year of work experience. Exclusion criteria were withdrawal from or lack of interest in participation in the study or incomplete filling out of questionnaires. Initially, necessary permissions were obtained from university authorities (decree code: IR.SUMS.REC.1396. S409). Also, oral and written informed consent was obtained from the students. They were assured of their anonymity and confidentiality of data throughout the study. Descriptive and inferential statistics via the SPSS software v.11 were used for data analysis. The statistics used to compare means and correlations, and for 
the regression were t-test, Pearson Correlation Coefficient and Linear Regression, respectively. The significance level was set as $p<0.05$.

The research instrument was consisted of three sections of demographic characteristics, Nonako and Takeuchi's knowledge management questionnaire ${ }^{(13,14)}$ and Randsip's creativity questionnaire. ${ }^{(15)}$ The knowledge management questionnaire was developed by Soltan Hosseini and Mousavi based on the Nonaka and Takeuchi model. It had 26 closed-ended questions with a five-option Likert scale for four dimensions of externalization (Questions 1-5), combination (Questions 6-16), internalization (Questions 17-20) and socialization (Questions 21-26). ${ }^{(13)}$ To assess the validity of the questionnaire, construct validity was used by exploratory factor analysis using varimax rotation (orthogonal) with Kaiser normalization, which was reported appropriate. ${ }^{(14)}$ Also, Content validity of this questionnaire was confirmed by faculty members. The reliability of this questionnaire using the calculation of the Cronbach's alpha coefficient was reported as $0.88 .{ }^{(13,14)}$

Randsip's creativity questionnaire was used for the evaluation of creativity. It had 50 questions with a five-point Likert scale $(+2=$ I fully agree, $+1=1$ agree, $0=\mid$ have no idea, $-1=\mid$ disagree, $-2=$ completely disagree). In this questionnaire, the range of scores was from - 100 to +100 with the higher score representing higher creativity. The rating scores were as follow: (80-100=very creative, $60-79=$ high average creativity, 40-59=moderate creativity, 20-39= creativity less than average, -100 to $-9=$ uncreative). Original Randsip's Creativity Questionnaire to measure an individual's level of creativity was developed by Randsip. Ivancevich and Matteson in the management and organizational behavior book in the chapter entitled "Decision" have been reported Randsip's Creativity Questionnaire as perfect instrument measure creativity in organizations with desirable reliability and validity. Except for items 4 and 39, the factorial load of 50 questions is between 0.30 and 0.58 . To evaluate the reliability of the questionnaire, the Cronbach's Alpha method was used and the calculated Coefficient was 0.74 which indicating appropriate reliability of the questionnaire. ${ }^{(15)}$ Validity of this translated questionnaire was assessed by Poursoltani Zarandi and Iraji (2014) using experts' perspectives. Its reliability using the calculation of the Cronbach's alpha coefficient was reported as 0.92. ${ }^{(16)}$

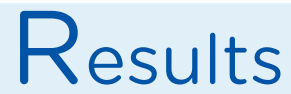

In this study $72.5 \%$ of bachelor degree students and $65 \%$ of Master degree student were women; this difference was statistically significant $(\chi 2=5.51, p=0.018)$. The mean age of the bachelor and master degree students' group were $22.03 \pm 2.66$ and $30.73 \pm 5.22$, respectively. Its $p$-value $t$-test was $p<0.001$ ).

There was a significant difference for the mean of the total score and for the dimensions externalization and combination between groups; higher scores were observed in the master degree nursing students for the total score and for the dimensions externalization and combination. (Table 1) 
Table 1. Comparison of the mean of knowledge management by dimensions by group of students

\begin{tabular}{|c|c|c|c|}
\hline \multirow[t]{2}{*}{ Dimension } & $\begin{array}{c}\text { Bachelor degree } \\
n=120\end{array}$ & $\begin{array}{c}\text { Master degree } \\
\quad n=60\end{array}$ & \multirow[t]{2}{*}{ t-test $p$-value } \\
\hline & Mean \pm S.D & Mean \pm S.D & \\
\hline Externalization & $3.27 \pm 0.77$ & $3.64 \pm 0.62$ & 0.002 \\
\hline Combination & $3.24 \pm 0.63$ & $3.51 \pm 0.56$ & 0.005 \\
\hline Internalization & $3.06 \pm 0.87$ & $3.00 \pm 0.71$ & 0.62 \\
\hline Socialization & $3.12 \pm 0.76$ & $3.28 \pm 0.66$ & 0.17 \\
\hline Total & $3.17 \pm 0.75$ & $3.35 \pm 0.63$ & 0.02 \\
\hline
\end{tabular}

Also, according to the Randsip's creativity scores, the level of creativity in bachelor degree students was worse than in master degree students $(80.8 \%$ versus $65 \%$ of uncreative and lower than the average, respectively by group), and this finding was significant $(\chi 2=8.48, p=0.003$ ) (Table 2).

Table 2. Distribution of creativity levels by group of students

\begin{tabular}{lll}
$\begin{array}{ll}\text { Group } \\
\text { Creativity level }\end{array}$ & $\begin{array}{l}\text { Bachelor degree } \\
n(\%)\end{array}$ & $\begin{array}{l}\text { Master degree } \\
n(\%)\end{array}$ \\
Uncreative & $46(38.3 \%)$ & $13(21.7 \%)$ \\
Lower than the average & $51(42.5 \%)$ & $26(43.3 \%)$ \\
Average & $11(9.2 \%)$ & $13(21.7 \%)$ \\
Higher than the average & $12(10 \%)$ & $8(13.3 \%)$ \\
Very creative & $0(0 \%)$ & $0(0 \%)$ \\
\hline
\end{tabular}

The results of the Pearson correlation coefficients (Table 3) showed that there was a direct, positive and significant relationship between the total score of knowledge management and creativity in the bachelor and master degree students with moderate and low correlations, respectively.

Table 3. Comparison of the correlation between knowledge management and creativity scores by group of students

\begin{tabular}{|c|c|c|}
\hline \multirow{2}{*}{ Knowldge management } & \multicolumn{2}{|c|}{ Creativity } \\
\hline & Bachelor degree & Master degree \\
\hline Externalization & $0.41 * * *$ & $0.41 * * *$ \\
\hline Combination & $0.50 * * *$ & $0.31 * *$ \\
\hline Internalization & $0.37 * * *$ & $0.08^{*}$ \\
\hline Socialization & $0.40 * * *$ & $0.47 * * *$ \\
\hline Total & $0.47 * * *$ & $0.36 * *$ \\
\hline
\end{tabular}

${ }^{*}: p>0.05,{ }^{* *}: p<0.01, * * *: p<0.001$ 
According to the results of the regression test, the multiple correlation coefficients of the four factors of externalization, combination, internalization and socialization, and the creativity were reported as 0.24 . Also, determination coefficient indicated that $0.26 \%$ of changes in creativity were determined by these four factors. Of the dimensions of knowledge management, combination with $\beta=0.37$ had the highest share in explaining the variables of creativity in bachelor's degree students. Also, the multiple correlation coefficients of the four factors of externalization, combination, internalization and socialization, and the creativity were reported as 0.30 . The determination coefficient indicated that $0.34 \%$ of changes in creativity were explained by these four factors. Of the dimensions of knowledge management, the dimension of socialization $(\beta=0.69)$ had the greatest contribution to explaining the variables of creativity in the master degree students.

\section{Discussion}

In this study, the relationship between knowledge management and creativity in bachelor degree nursing students compared with master degree nursing students was assessed. The findings of the study showed that there was a positive and significant relationship between knowledge management and creativity in the students, so that the highest correlation was found between knowledge management and creativity in the dimension of 'combination' in the bachelor degree students. Also, the highest correlation between knowledge management and creativity was reported in the dimension of 'socialization' in the master degree students. It should be noted that there were a few studies on the basis of knowledge management dimensions of the Nonako and Takeuchi models. Therefore, in reviewing related research in this section, it was inevitable to cite articles related to these dimensions.

According to the results of this study, there was a significant difference between the mean scores of knowledge management in the bachelor degree students and master degree students; so that the mean scores of knowledge management in the master degree students were higher than the bachelor degree students. In another study, students with PhD degree education had a higher knowledge management score. ${ }^{(17)}$ Interactions and discussions in master degree classes provide a convenient platform for knowledge development. On the other hand, knowledge generation as a result of research projects and homework assignments provides a platform for individual growth $^{(1)}$ It seems that students' activities in higher education levels are associated with a deeper knowledge and understanding. Also, they emphasis on knowledge-based organizations, rather than production-driven organizations and up-to-date knowledge.

Based on the findings of this study, the scores of externalizing, combination and socialization in the master degree students were higher than those of the bachelor degree students. In a study on medical students in the field of knowledge management, they acquired the highest score in knowledge saving. ${ }^{(17)}$ In the study by Hassanian et al's, research was the most important knowledge production strategy in nursing students. ${ }^{(1)}$ The results of a study showed that knowledge management was facilitated through sharing information and sharing learning. ${ }^{(18)}$ Master degree students in this study used these strategies more than the bachelor degree students. They made knowledge available to other students, personalized hidden knowledge privately and exchange it with other students. In addition, they shared their views, experiences, and mental models through face-to-face social interactions to develop knowledge with others. However, bachelor degree students were more likely to use internalization, which means translating objective and obvious knowledge through its interpretation into hidden knowledge and was accomplished through learning in action. ${ }^{(19)}$ It should be noted that in the undergraduate nursing studies, the present study emphasizes learning mainly in the clinical setting. Academic educators and clinical 
nurses are the largest source of learning for undergraduate students. However, in the master degree education, besides learning in the clinical setting, nursing research and the application of nursing theories in practice are emphasized. Therefore, undergraduate students use group discussions, interactions with peers and nursing educators, critical questions and research in nursing practice.

According to the findings of this study, there was a significant difference between the mean score of creativity in the bachelor degree and the master degree students, so that the mean score of creativity in the master degree students was higher than that of the bachelor degree students. In addition, the creativity scores of both groups were ranked below the moderate level. In the Sadeghi et al's study, the fourth year nursing students had a higher score of creativity than the first year students. ${ }^{(20)}$ The results of the Rogal and Young's (2008) study showed that the critical thinking skills of most masters nursing students was increased during their studies. ${ }^{(21)}$ Knowledge gained by undergraduate nursing students is thought to have a short half-life. As a result, other students should be able to access this information and apply it in clinical settings. However, the activities of postgraduate students have come with a deeper knowledge and understanding. Perhaps the difference between the bachelor degree and master degree students of this study can be attributed to the effects of undergraduate education in developing creativity skills on tacit learning, career records, problem solving skills, decision making, participation in workshops, and clinical experience in the master degree students.

According to the findings of the present study, there was a direct and positive correlation between knowledge management and creativity in the students. The higher the level of knowledge management, the higher the student's creativity. In this study, the highest correlation was between knowledge management in the dimension of 'combination' and creativity in the bachelor degree students. In the master degree students, the highest correlation was between the dimensions of 'socialization' and creativity. It is believed that the use of knowledge management leads to the development of creativity and improvement of performance. ${ }^{(22,23)}$ In another research, the effect of knowledge sharing on innovation was reported as there was a significant relationship between knowledge sharing and innovation. ${ }^{(24)}$ In a study, knowledge acquisition strategies, knowledge transfer, and knowledge application and protection led to the development of staff performance. ${ }^{(25)}$ The dynamic of mental factors play an important role in the production of knowledge, and nursing students need a creative and curious mind to develop knowledge. According to the results, knowledge management activates creativity among students, that influences the use of knowledge for problem solving and creativity, and the interaction of these variables develops performance and improves creativity. In the master degree students, the highest correlation was between the dimensions of 'socialization' and creativity. In the master degree students, the more the knowledge becomes available to all students, they are able to use it whenever and wherever it is needed, defined as moving from explicit individual knowledge to explicit group knowledge. Such knowledge is stored, the problem can be solved by the group and the resulting knowledge is more developed. However, to improve creativity, the master degree students use hidden knowledge transfer strategies and redistribute it to hidden knowledge, share their experiences and mental models to improve other students, have mutual understandings through face-to-face social interactions, share their thoughts through brain storming, practice, education and exchange of ideas.

The strengths of this study are that in previous studies, some aspects of knowledge management, such as saving knowledge and how to transfer hidden knowledge have been mentioned. Given that the Knowledge Management Model of Nonaka and Takeuchi considers all dimensions of knowledge management, universities and health centers authorities can use knowledge management as a conscious strategy for identifying knowledge, evaluating, organizing and 
storing it to enhance students' and employees' creative community services at all levels. A limitation of this study was that the mental status of nursing students could have influenced their responses when completing the questionnaires, which was outside of the researcher's control. Also, not sufficient studies were available in the nursing literature on this topic. It is suggested that to create effective knowledge management and increase the creativity of bachelor and master degree nursing students, courses for familiarization with knowledge management and its dimensions are held. It is also suggested that this study is repeated with a larger sample and comparative studies in other public and private university institutes and health centers are conducted. It is also possible to compare the level of knowledge management and creativity of different universities for ranking universities in terms of the existence of these components.

Conclusion. The findings of this study showed that there was a direct and significant relationship between knowledge management and creativity in the bachelor and master degree students. While the mean scores of some aspects of knowledge management and the score of creativity were higher in the master degree students, the scores of both groups of students on the level of knowledge management were in a moderate level and in relation to creativity were lower than the average level. The requirement of educational environments is the existence of knowledge management, which makes the development of knowledge for all individuals at different levels and groups possible. Also, it helps with sharing and using classified learning. Therefore, more attention should be paid to all aspects of knowledge management in all levels to create an environment for students to address health challenges in the society. In such an environment, creativity, innovation, fertility of ideas and knowledge transfer will become possible.

Acknowledgements: This study was a result of a research project approved by Shiraz University of Medical Sciences, Iran (decree code: 1396-0108-14490). Therefore, the authors are grateful to the university research committee and the sincere cooperation of the nursing students. 


\section{References}

1. Hassanian ZM, Ahanchian MR, Ahmadi S, Gholizadeh RH, Karimi-Moonaghi H. Knowledge creation in nursing education. Glob. J. Health Sci. 2015; 7(2):44-55.

2. Anderson JA, Willson P. Knowledge management: organizing nursing care knowledge. Crit. Care Nurs. Q. 2009; 32(1):1-9.

3. Laal M. Knowledge management in higher education. Procedia Comput. Sci. $2011 ; 3: 544-9$.

4. Hassanian ZM, Ahanchian MR, Karimi-Moonaghi H. Can Knowledge Management Be Implemented in the Teaching of Medical Sciences? Acta Fac. Med. Naiss. 2015; 32(4):231242.

5. Hsu I, Sabherwal R. Relationship between intellectual capital and knowledge management: an empirical investigation. Decis. Sci. 2012; 43(3):489-524.

6. Jones $\mathrm{JH}$, Morris LV. Evaluation of critical thinking skills in an associate degree nursing program. Teach. Learn. Nurs. 2007;2(4):109-15.

7. Kothari A, Rudman D, Dobbins M, Rouse M, Sibbald S, Edwards N. The use of tacit and explicit knowledge in public health: a qualitative study. Implement Sci. 2012; 7(1):20.

8. Revere D, Turner AM, Madhavan A, Rambo N, Bugni PF, Kimball A, et al. Understanding the information needs of public health practitioners: a literature review to inform design of an interactive digital knowledge management system. J. Biomed Inform. 2007; 40(4):410421.

9. Rocha ESB,Nagliate P, Furlan CEB, Jr KR, Trevizan MA, Mendes lac. Knowledge management in health: A systematic literature review. Rev. Latino-Am. Enfermagem. 2012; 20(2):392-400.

10. Baezat S, Aflakifard $\mathrm{H}$, Shahidi $\mathrm{N}$. The relationship between knowledge management and self-efficacy and creativity of teacher centers Before Elementary school. IRJABS. 2017;7(4):169-184.

11. Xu D, Wang D, editors. The Effects of Knowledge Management on the Process of Employee Innovation within Organizations. 2014 International Conference on Management, Education and Social Science (ICMESS 2014); 2014: Atlantis Press.

12. Ahmadvand A, Movahedi M, Ghazizzadehfard SX, Mohammad Pour S. Designing Knowledge Management Systems of Health-Oriented Organization. Iran. J. Nurs. Res. 2017; 12(4):76-82.

13. Soltan Hosseini M, Mousavi Z. The survey of relative ratio of knowledge management on organizational health in Esfahan Physical Education Offices. Sport Motor Sci. Res. 2013;2(3):51-71.

14. Hossaingholizadeh R, Shaabanivarki B, Mortazavi S. Relationship between organizational culture and knowledge management in higher education (Case: Ferdowsi University of Mashad, Iran). Stud. Educ. Psycholog. 2005; 10,6:5-27.

15. Taghi L, Khajeey S, Mahmoudi AM. Investigation of the strategies to promote teachers creativity through the educational principals of education department of Razan city of Iran. J. Appl. Environ.Biol.Sci. 2012; 2(12), 658-70.

16. Poursoltani H, Iraji R. The relationship between knowledge management and employees creativity in physical education organization of Ferdowsi University of Mashhad. J. Hum. Resour. Manag. Sport. 2014; 1(1):61-71.

17. Yaghoubi M, Javadi M, Agharahimi Z. The Relationship between Knowledge Management and Demographic Features of Students in Isfahan University of Medical Sciences. Iran. J. Med. Educ. 2010; 10(5):831-8.

18. Lunden A, Teräs $M$, Kvist $T$, Häggman-Laitila A. A systematic review of factors influencing knowledge management and the nurse leaders' role. J. Nurs. Manag. 2017; 25(6):407-20.

19. Tavakoli Z, Gandomani TJ. Adaptation of Nanoka's and Takeuchi's knowledge management model to Scrum roles. Int. J. Softw. Eng.Technol. 2016; 2(1):16-9.

20. Sadegi-Gandomani HR. Delaramm, Nasiri-Ziba F, Naseri-Boroujeni N. Assessment the creative skills of nursing students and nurses in the intensive care units of hospitals govered by Tehran University of Medical Sciences. Res. Med. Educ. 2015; 7(3):11-6 
21. Rogal SM, Young J. Eaploring critical thinking in critical care nursing education. J. Contin. Educ. Nurs. 2008; 39(1):28-33.

22. Rezaei Z, Rezaei A, Lati M. Survey the role of management on the creativity and innovation to create sustainable competitive advantage for organization. Indian J. Fundament Appli. Life Sci. 2015; 5(S1):1830-6.

23. Kör B, Maden C. The relationship between knowledge management and innovation in Turkish service and high-tech firms. Int. J. Bus. Soc. Sci. 2013; 4(4):293-304.

24. Kamaşak R, Bulutlar F. The influence of knowledge sharing on innovation. Eur. Bus Rev. 2010; 22(3):306-17.

25. Ha S-T, Lo M-C, Wang Y-C. Relationship between knowledge management and organizational performance: a test on SMEs in Malaysia. Procedia Soc. Behav. Sci. 2016; 224:184-9. 